\title{
Transient expression of $\beta C 1$ protein differentially regulates host genes related to stress response, chloroplast and mitochondrial functions
}

\author{
Saiqa Andleeb, Imran Amin, Aftab Bashir, Rob W Briddon, Shahid Mansoor
}

\begin{abstract}
Background: Geminiviruses are emerging plant pathogens that infect a wide variety of crops including cotton, cassava, vegetables, ornamental plants and cereals. The geminivirus disease complex consists of monopartite begomoviruses that require betasatellites for the expression of disease symptoms. These complexes are widespread throughout the Old World and cause economically important diseases on several crops. A single protein encoded by betasatellites, termed $\beta C 1$, is a suppressor of gene silencing, inducer of disease symptoms and is possibly involved in virus movement. Studies of the interaction of $\beta C 1$ with hosts can provide useful insight into virus-host interactions and aid in the development of novel control strategies. We have used the differential display technique to isolate host genes which are differentially regulated upon transient expression of the $\beta C 1$ protein of chili leaf curl betasatellite (ChLCB) in Nicotiana tabacum.

Results: Through differential display analysis, eight genes were isolated from Nicotiana tabacum, at two and four days after infitration with $\beta C 1$ of $C h L C B$, expressed under the control of the Cauliflower mosaic virus 355 promoter. Cloning and sequence analysis of differentially amplified products suggested that these genes were involved in ATP synthesis, and acted as electron carriers for respiration and photosynthesis processes. These differentially expressed genes (DEGs) play an important role in plant growth and development, cell protection, defence processes, replication mechanisms and detoxification responses. Kegg orthology based annotation system analysis of these DEGs demonstrated that one of the genes, coding for polynucleotide nucleotidyl transferase, is involved in purine and pyrimidine metabolic pathways and is an RNA binding protein which is involved in RNA degradation.

Conclusion: $\beta C 1$ differentially regulated genes are mostly involved in chloroplast and mitochondrial functions. $\beta C 1$ also increases the expression of those genes which are involved in purine and pyrimidine metabolism. This information gives a new insight into the interaction of $\beta C 1$ with the host and can be used to understand hostvirus interactions in follow-up studies.
\end{abstract}

\section{Background}

Geminiviruses are economically important plant pathogens and are characterized by twinned isometric particles containing single-stranded (ss)DNA genomes of 2.5-3.0 kb [1] that replicate through double-stranded (ds)DNA intermediates by a rolling-circle mechanism [2]. The family Geminiviridae is divided into four genera, (Begomovirus, Mastrevirus, Curtovirus and Topocuvirus) that encompass viruses that differ in genome

\footnotetext{
*Correspondence: shahidmansoor7@gmail.com

Agricultural Biotechnology Division, National Institute for Biotechnology and Genetic Engineering, Faisalabad, Pakistan
}

organization as well as their insect vectors. Begomoviruses are transmitted by the whitefly Bemisia tabaci and have either monopartite or bipartite genomes. Monopartite begomoviruses are often associated with circular, ssDNA satellites that are collectively referred to as betasatellites (formerly known as DNA $\beta$ ). Betasatellites have recently been found to be associated with some bipartite begomoviruses and are required by some of their helper begomoviruses to induce bona fide disease symptoms in plants. Numerous economically important diseases and even the earliest recorded plant

\section{Biomed Central}


viral disease are now known to be caused by begomovirus/betasatellite complexes $[3,4]$.

Betasatellites are widespread in the Old World, where monopartite begomoviruses are known to occur. Numerous distinct betasatellites, from various economically important hosts and diverse locations, have been cloned and have been found in most cases to contribute significantly to disease symptoms [5]. Analysis of betasatellite sequences reveals a highly conserved organization consisting of an adenine-rich region and a region of sequence highly conserved between all betasatellites (known as the satellite conserved region [SCR]). The SCR contains a potential hairpin structure with the loop sequence TAA/GTATTAC that has similarity to the origins of replication of geminiviruses and nanoviruses. Betasatellites encode only a single gene, known as the bC1, located on the complementary-sense strand, is conserved in position and size in all betasatellites $[6,7]$.

Chilli leaf curl betasatellite (ChLCB) is associated with chilli leaf curl disease (ChLCuD), a significant constrain to chilli production across the Indian subcontinent $[8,9]$. Saeed et al. [5] demonstrated that tobacco plants transformed with the $\beta C 1$ of Cotton leaf curl Multan betasatellite (CLCuMB) under the control of the Cauliflower mosaic virus 35S promoter, or with a dimer of CLCuMB, exhibited severe diseaselike phenotypes, while plants transformed with a mutated version of the $\beta C 1$ appeared normal. Qazi et al. [10] showed that expression of CLCuMB $\beta C 1$ from a Potato virus $X$ vector induced symptoms typical of cotton leaf curl disease (CLCuD) in the absence of the helper begomovirus. These results demonstrated that CLCuMB $\beta C 1$ is the major determinant of symptoms of the CLCuD complex [10].

The interactions between plants and viruses are complex and involve several types of responses that may or may not cause disease in the host [11]. In compatible interactions, the invading virus is able to infect and replicate within a susceptible plant to cause disease. Alternatively, the host may trigger innate immunity mechanisms that restrict virus movement and prevent disease onset. In both situations, viral pathogens severely disturb plant growth and development, due to their effect on cellular metabolism [11]. Viral infection produces a plethora of symptoms derived from biochemical and metabolic changes in cells, tissues and even in the whole plants which are susceptible and hypersensitive resistant hosts. Huang et al. [12] and Sui et al. [13] demonstrated that plant viruses cause severe impact on host gene expression and protein activity due to the activation of a set of genes and the inactivation of others. The gene expression profile in the host plant changes according to the timing and localization of the infection, as the virus spreads from cell to cell away from the site of inoculation $[14,15]$.

The present studies are aimed at identifying host genes and pathways that are induced by ChLCB $\beta C 1$. This may be achieved using differential RNA display technology. This technique is based on "differential display reverse transcriptase polymerase chain reaction" (DDRT-PCR), first described by Liang and Pardee [16]. This method has the advantage of technical simplicity, a lower bias against rare messages and a requirement of only small quantities of starting mRNA. Several modifications of the original technique have been reported with some solutions to the key problems identified by some authors [17]. Stress responses have been studied using DDRT-PCR in C. elegans and S. cerevisiae [18-20]. DDRT-PCR has been applied in many laboratories to identify genes involved in signal cascades.

The identification of host genes affected by ChLCB $\beta C 1$ may provide useful insights into virus-host interactions and provide targets for novel control strategies. By differential display analysis we have identified $N$. tabacum genes differentially regulated in response to the transient expression of ChLCB $\beta C 1$ protein. Subsequently the effects of $\beta C 1$ expression on each gene identified were verified by quantitative real time PCR analysis.

\section{Results and Discussion}

We have made a further modification of the DDRT-PCR technique by utilizing the mRNA fraction instead of total RNA and by resolving the products of DDRT-PCR on 1\% agarose gels stained with ethidium bromide [16]. We have identified several genes which were differentially expressed at 2 dpi and 4 dpi. Two different concentrations of cDNA (100 ng/ $\mu \mathrm{l}$ and $10 \mathrm{ng} / \mu \mathrm{l}$; Figures $1 \mathrm{~A}-\mathrm{F}$ ) were used, of which ninety seven differentially expressed genes (DEGs) were amplified by different anchored and arbitrary primer pairs (Table 1; Figures $1 \mathrm{~A}-\mathrm{F})$. The anchored and arbitrary are random decamer primers, and used as reverse and forward primer for cDNA synthesis. Agroinfiltration was used for transient expression of $\beta C 1$ (ChLCB) under $35 \mathrm{~S}$ promoter. DDRT-PCR showed different bands of transcripts in comparison to control plants. Some of the primer combinations did not yield an amplification product (Figures 1A-F). At 2 dpi no difference was observed in control and infected plants as indicated in DD10 (B7, B18); DD11 (B15, B16, B19); and DD12 (B11, B19), respectively (Figures $1 \mathrm{~A}-\mathrm{C}$ ). On the other hand, at 4 dpi same pattern was also observed in DD10 (B2, B3, B4, B8, B10, B14, B17, B18, B20), DD11 (B2, B6, B7, B9, B10, B11, B12, B13, B16, B17, B18), and DD12 (B6, B7, B11, B14, B15) respectively (Figures 1D-F). 


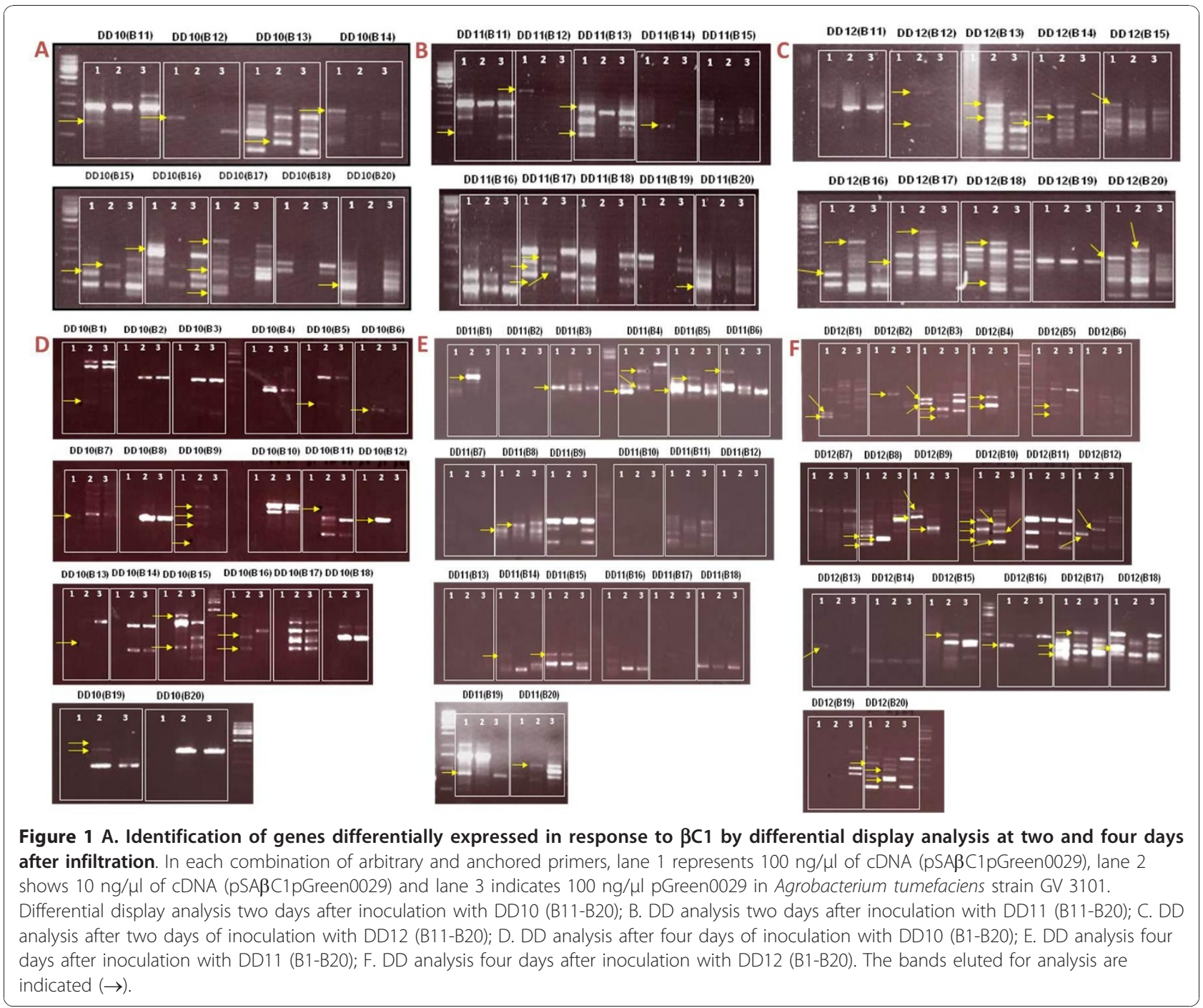

Analysis of DEGs identified at two days post infiltration Differentially expressed products were cloned and sequenced. The identity of these differentially expressed genes was analysed using NCBI nucleotide data blast system. The ratio of differentially expressed genes (SA1, SA2, SA3, SA4, SAA, SAB, SAC and SAD) expressed in a sample versus a calibrator (healthy plant and plant infiltrated with pGreen0029) in comparison to a reference gene (rubisco) is indicated in the Tables 2, 3 and 4. The results of Delta Delta $(\mathrm{Ct})$, Livak and the Pfaffi mathematical models indicated that SAA, SAB, SAD, SA1, SA2, and SA3 mRNA expression were upregulated in sample compared to the calibrator (plant inoculated with pGreen0029 and healthy plant). Interestingly elevation of mRNA transcripts was also detected by RT-PCR (Figure 2A and 2B). In contrast SAC and SA4 mRNA expression was down regulated in the sample compared to the calibrator (Figure 2A and 2B). The calculated expression levels by these models is indicated in the Tables 2, 3 and 4 .

The results indicated that SAA showed $76 \%$ nucleotide sequence identity with Solanum lycopersicum WRKY transcription factor IId-1 splice. The results show that the SAA gene is upregulated (Figure 2) upon inoculation with the ChLCuB $\beta C 1$ gene, which is a pathogenicity determinant [21-23], helps in viral movement, is involved in symptom induction $[9,24,25]$, is a suppressor of gene silencing [26] and may be the target of a host response that up-regulates WRKY transcription factors [27]. It has been shown that the transcription of WRKY genes are strongly and rapidly upregulated in response to wounding, pathogen infection or abiotic stresses in numerous plant species, as indicated in Figure 3[28]. Infection of tobacco with Tobacco mosaic virus (TMV) or bacteria, or treatment with fungal elicitors, salicylic acid (SA) or $\mathrm{H}_{2} \mathrm{O}_{2}$, strongly induces several WRKY genes $[29,30]$. 
Table 1 Sequences of oligonucleotide primers used in the study

\begin{tabular}{|c|c|c|}
\hline Use & Primer & Sequence \\
\hline & Anchored Primer & \\
\hline & DD10 & 5'-TाTाIIITाTG-3' \\
\hline \multirow[t]{12}{*}{ CDNA } & DD11 & 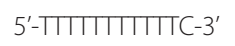 \\
\hline & DD12 & 5'-TाTाताITाTA-3' \\
\hline & Arbitrary Primer & \\
\hline & B-01 & 5'-GTTCGCTCC-3' \\
\hline & B-02 & 5'-TGATCCCTGG-3' \\
\hline & B-03 & 5'-CATCCCCCTG-3' \\
\hline & B-04 & 5'-GGACTGGAGT-3' \\
\hline & B-05 & 5'-TGCGCCCTTC-3' \\
\hline & B-06 & 5'-TGCTCTGCCC-3' \\
\hline & B-07 & 5'-GGTGACGCAG-3' \\
\hline & B-08 & 5'-GTCCACACGG-3' \\
\hline & B-09 & 5'-TGGGGGACTC-3' \\
\hline \multirow[t]{11}{*}{ DDRT-PCR } & B-10 & $5^{\prime}$-CTGCTGGGAC-3' \\
\hline & B-11 & 5'-GTAGACCCGT-3' \\
\hline & B-12 & 5'-CCTTGACGCA-3' \\
\hline & B-13 & 5'-TTCCCCCGCT-3' \\
\hline & B-14 & 5'-TCCGCTCTGG-3' \\
\hline & B-15 & 5'-GGAGGGTGTT-3' \\
\hline & B-16 & 5'-TाTGCCCGGA-3' \\
\hline & $B-17$ & $5^{\prime}-A G G G A A C G A G-3^{\prime}$ \\
\hline & B-18 & $5^{\prime}$-CCACAGCAGT-3' \\
\hline & B-19 & 5'-ACCCCCGAAG-3' \\
\hline & $B-20$ & 5'-GGACCCTTAC-3' \\
\hline
\end{tabular}

This suggests that the expression of $\beta C 1$ gene results in a stress response and the plant responds to these stresses by increasing the transcription of WRKY genes.

SAB showed 68\% nucleotide sequence identity with $A$. thaliana putative Rieske iron-sulfur protein (RISP) and $73 \%$ with $P$. sativum RISP. The expression of SAB was upregulated in the response of ChLCB $\beta C 1$ (Figure 2).
RISP was identified from expression of betaC1 gene [31] and is absolutely required for mitochondrial respiration (Figure 3) as reported earlier [32,33]. Mitochondrial RISP is encoded by a nuclear gene, translated as a precursor protein in the cytoplasm and post-translationally imported into mitochondria. Huang [34] demonstrated that the RISP gene family is differentially regulated; higher RISP levels occur in flowers than in leaves, stems and roots. RISP is involved in energy production in the form of ATP, required for pollen development and must be supplied mainly by mitochondria. Similarly, flower mitochondria could meet the high demand for energy either by increasing their metabolic activity to generate more ATP per mitochondrion or by increasing their number per cell so that more ATP is produced [35]. It has been shown that expression of $\beta \mathrm{C} 1$ results in foliar enations [10], which is an indication of enhanced cell division. Cell division is an energy requiring process. Therefore one possible pathway to acquire energy is via RISP proteins (Figure 3). However, this hypothesis will require further experimental confirmation.

The SAC DNA sequence shows 93\% nucleotide sequence identity with both NADH dehydrogenase subunit 1 (ndh1) and NADH dehydrogenase subunit 2 (ndh2) of $N$. tabacum mitochondrial genes, also known as $\mathrm{NADH}$ oxidoreductase. Similar to the SAB, it has been demonstrated that SAC is a $N$. tabacum mitochondrial protein and also involved in generation of cellular energy in the form of ATP by building the electrochemical potential in electron transport chain as indicated in (Figure 3) $[35,36]$. The SAD transcript showed $47 \%$ nucleotide sequence identity with the $M$. truncatula quinon protein alcohol dehydrogenase. The quinon protein alcohol dehydrogenases are involved in plant development and senescence, reducing the concentration of toxic amines during stress conditions, and providing hydrogen peroxide for wall stiffening and lignification (Figure 3).

Table 2 Conclusion of relative quantification methods of differentially expressed genes at two and four days after inoculation

\begin{tabular}{llll}
\hline DEG & $\begin{array}{l}\text { Length } \\
\text { bps }\end{array}$ & Identity & $\begin{array}{l}\text { Up/Down } \\
\text { regulation }\end{array}$ \\
\hline SAA & $(287)$ & S. lycopersicum WRKY transcription factor Ild-1 splice & Upregulated \\
\hline SAB & $(231)$ & $\begin{array}{l}\text { Putative Rieske iron-sulfur protein [A. thaliana]Length = 539, Rieske iron-sulfur protein Tic55 [P. sativum]Length = } \\
553\end{array}$ & Upregulated \\
\hline SAC & $(386)$ & $\begin{array}{l}\text { N. tabacum mitochondrial DNA, complete genome Length = 430597 NADH dehydrogenase subunit 1 NADH } \\
\text { dehydrogenase subunit 2, 846 bp at 5' side: }\end{array}$ & Down regulated \\
\hline SAD & $(262)$ & Quinonprotein alcohol dehydrogenase like M. truncatula & Upregulated \\
\hline SA1 & $(442)$ & Trigger factor (chaperone in protein export) & Upregulated \\
\hline SA2 & $(688)$ & A. thaliana calmodulin-binding receptor-like kinase & Upregulated \\
\hline SA3 & $(772)$ & Polyribonucleotide nucleotidyltransferase & Upregulated \\
\hline SA4 & $(283)$ & Chromosomal replication initiator protein DnaA & Down regulated \\
\hline
\end{tabular}


Table 3 Relative quantification methods of differentially expressed genes two days post inoculation

\begin{tabular}{|c|c|c|c|c|c|c|}
\hline \multirow[t]{2}{*}{ Genes } & \multirow[t]{2}{*}{ Identity } & \multicolumn{2}{|c|}{$\begin{array}{l}\text { Relative } \\
\text { quantification } \\
\text { against Unit } \\
\text { mass }\end{array}$} & \multicolumn{3}{|c|}{$\begin{array}{l}\text { Relative quantification } \\
\text { Normalized to a reference } \\
\text { gene }\end{array}$} \\
\hline & & Control & Healthy & $\begin{array}{l}\text { Livak } \\
\text { method }\end{array}$ & $\begin{array}{l}\Delta C T \\
\text { Method }\end{array}$ & $\begin{array}{l}\text { Pfaffi } \\
\text { Method }\end{array}$ \\
\hline SAA & S. Iycopersicum WRKY transcription factor IId-1 splice & 2.32 & 1.32 & $\begin{array}{l}0.737 \mathrm{Cl} \\
0.381 \mathrm{H}\end{array}$ & $\begin{array}{l}0.942 \mathrm{Cl} \\
0.838 \mathrm{H}\end{array}$ & $\begin{array}{l}0.737 \mathrm{Cl} \\
0.381 \mathrm{H}\end{array}$ \\
\hline SAB & $\begin{array}{l}\text { Putative Rieske iron-sulfur protein }[\text { A. thaliana }] \text { Length }=539 \text {, Rieske iron-sulfur protein } \\
\text { Tic55 }[\text {. sativum]Length }=553\end{array}$ & 2.751 & 0.566 & $\begin{array}{l}0.870 \mathrm{C} / \\
0.162 \mathrm{H}\end{array}$ & $\begin{array}{l}0.972 \mathrm{Cl} \\
0.728 \mathrm{H}\end{array}$ & $\begin{array}{l}0.870 \mathrm{Cl} \\
0.162 \mathrm{H}\end{array}$ \\
\hline SAC & $\begin{array}{l}\text { N. tabacum mitochondrial DNA, complete genome Length }=430597 \mathrm{NADH} \\
\text { dehydrogenase subunit } 1 \mathrm{NADH} \text { dehydrogenase subunit } 2,846 \text { bp at } 5^{\prime} \text { side }\end{array}$ & 0.010 & 1.905 & $\begin{array}{l}0.003 \mathrm{C} / \\
0.547 \mathrm{H}\end{array}$ & $\begin{array}{l}-0.672 \mathrm{Cl} \\
1.355 \mathrm{H}\end{array}$ & $\begin{array}{l}0.003 \mathrm{Cl} \\
0.547 \mathrm{H}\end{array}$ \\
\hline SAD & Quinonprotein alcohol dehydrogenase like [M. truncatula] & 5.205 & 0.829 & $\begin{array}{l}1.647 \mathrm{Cl} \\
0.238 \mathrm{H}\end{array}$ & $\begin{array}{l}1.167 \mathrm{Cl} \\
0.707 \mathrm{H}\end{array}$ & $\begin{array}{l}1.647 \mathrm{C} / \\
0.238 \mathrm{H}\end{array}$ \\
\hline
\end{tabular}

Analysis of DEGs identified at four days post infiltration Several genes were also identified that were differentially expressed at 4 dpi. DEG SA1 shows 99\% nucleotide sequence identity with trigger factor (chaperone in protein export) of $P$. acnes. It has been suggested that molecular chaperones play a critical role in targeting proteins to the mitochondria, are involved in $\mathrm{Ca}^{+}$ dependent signaling pathway (Figure 3) and in the subsequent folding of the imported protein [37-39]. It may be very useful to analyze the interaction of $\beta C 1$ with chaperones through protein-protein interaction in future. It has been shown that SA2 transcript belongs to the primary calcium receptor called calmodulin (CaM; Figure 3), which is a ubiquitous protein found in both plants and animals [40]. It is located in cytoplasmic and nuclear compartments and can be attached to the plasma membrane in plant cells $[41,42]$.

SA2 showed $72 \%$ nucleotide sequence identity with A. thaliana calmodulin-binding receptor-like kinase 2 (CRCK2) and, interestingly, the expression of CRCK1 is up-regulated by cold and salt stresses, as well as the stress molecules ABA (abscisic acid) and hydrogen peroxide, suggesting that CRCK2 may be involved in osmotic and oxidative stress signal transduction pathways in plants [43]. It has been suggested that CRCK2 protein is up regulated (Figure 2 ) during pathogen infection and also regulates the activities of a wide range of $\mathrm{CaM}$ binding proteins (CaMBPs), including metabolic enzymes, transcription factors such as WRKY group II d [44], ion channels, protein kinases/phosphatases and structural proteins $[45,46]$, as indicated in Figure 3.

Transcript SA3 showed 92\% nucleotide sequence identity with the polynucleotide nucleotidyltransferase from P. cryohalolentis K5 (PNPase; encoded by the pnp gene). PNPase is an RNA binding protein, involved in posttranscriptional gene silencing, participates in RNA degradation [47] and plays a central role in adaptation to growth at low temperature [48]. Previous studies identified PNPase in eubacteria [49-51], Drosophila melanogaster [52], plants [53,54], and even mice and humans $[55,56]$. Here it has been identified in N. tabacum in the response of $\beta C 1$ of ChLCB. SA 4 shows $90 \%$ nucleotide sequence identity with the chromosomal replication initiator protein DnaA. $\beta C 1$ induces cell proliferation (enations) and a requirement for DnaA during cell division is thus consistent with this finding. Sequence analysis of the cloned DEGs showed 8 of them to represent genes that have been previously characterized (Table 5), while the remainder represent genes of unknown function and hypothetical proteins predicted from sequence. All these genes are associated with chloroplast and mitochondrial host compartments.

Table 4 Relative quantification methods of differentially expressed genes four days post inoculation

\begin{tabular}{lllllll}
\hline Gene & Identity & \multicolumn{2}{l}{$\begin{array}{l}\text { Relative quantification against } \\
\text { Unit mass }\end{array}$} & \multicolumn{3}{l}{ Relative quantification normalized to a reference } \\
\cline { 3 - 7 } & & Control & Healthy & Livak method & \multicolumn{1}{c}{$\Delta$ CT Method } & Pfaffi Method \\
\hline SA1 & Trigger factor (chaperone in protein export) & 2.88 & 17.75 & $1.443 \mathrm{C} / 7.727 \mathrm{H}$ & $1.08 \mathrm{C} / 1.74 \mathrm{H}$ & $1.443 \mathrm{C} / 7.727 \mathrm{H}$ \\
\hline SA2 & A. thaliana calmodulin-binding receptor-like kinase & 3.759 & 3.759 & 8.564 & - & 8.564 \\
\hline SA3 & Polyribonucleotide nucleotidyltransferase & 1.32 & 1.70 & $0.664 \mathrm{C} / 0.742 \mathrm{H}$ & $0.790 \mathrm{C} / .837 \mathrm{H}$ & $0.664 \mathrm{C} / 0.742 \mathrm{H}$ \\
\hline SA4 & Chromosomal replication initiator protein DnaA & 0.659 & 0.882 & $0.329 \mathrm{C} / 0.253 \mathrm{H}$ & $0.674 \mathrm{C} / 0.706 \mathrm{H}$ & $0.329 \mathrm{C} / 0.253 \mathrm{H}$ \\
\hline
\end{tabular}



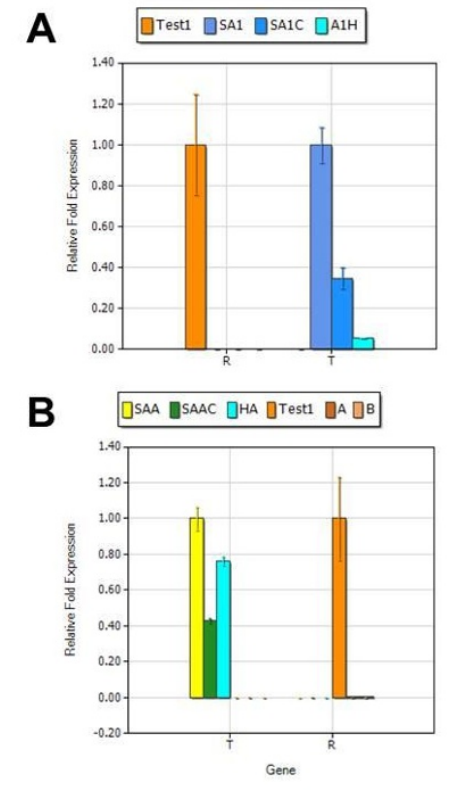
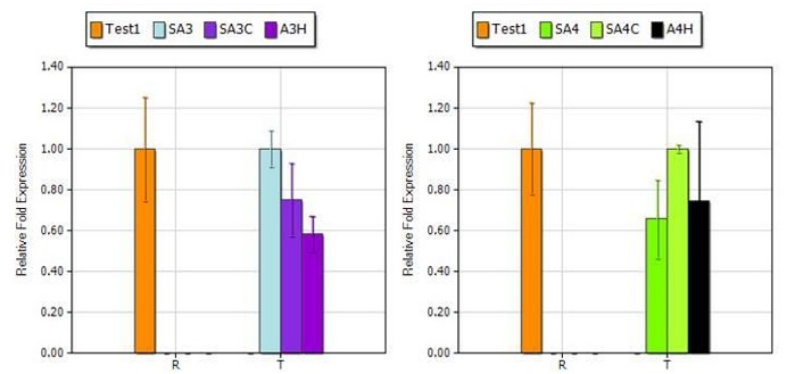

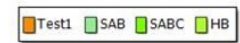

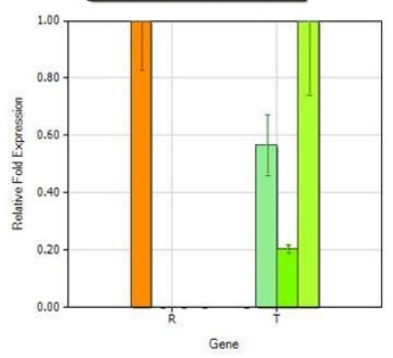

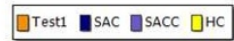

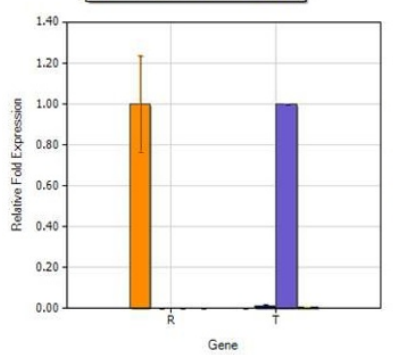

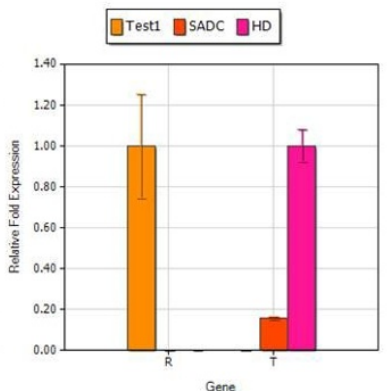

Gene

Figure 2 Quantitative real time RT-PCR analysis of DEGs identified in response to $\beta C 1$ at two and four days after infiltration of $N$. tabacum. SA1, SA2, SA3, SA4, SAA, SAB, SAC and SAD test samples with color indication represent the up and down regulation of differentially expressed genes as compared to calibrator having only pGreen0029 vector (SA1C, SA3C, SA4C, SAAC, SABC, SACC, SADC) and another healthy calibrator (A1H, A3H, A4H, HA, HB, HC and HD). In both (A) and (B) R stand for reference gene and T for test samples.

The results suggest that the DEGs identified in response to $\beta \mathrm{C} 1$ are involved in multiple pathways; oxidative stress signaling, $\mathrm{Ca}+$ dependent signaling, salicylic acid signaling pathways (Figure 3). Interestingly, these DEGs are related to specific cellular compartments, mitochondria and chloroplasts (Figure 3), where they act as electron carrier for respiration and photosynthesis by ATP synthesis (Figure 3). Collectively these genes perform their roles in plant growth and development, detoxification responses, cell protection and defense against invading viral proteins or pathogen (Figure 3).

\section{Analysis of DEGs using KOBAS}

The DEGs responsive to ChLCB $\beta C 1$ were analyzed using the KEGG orthology (KO) system, also called KOBAS (KO Based Annotation System). This showed that polyribonucleotide nucleotidyltransferase is involved in the purine and pyrimidine metabolic pathways (Table 6 and 7). These finding suggest that $\beta C 1$ interact with host genes in such a manner to increase the amount of purines and pyrimidines in the cells and this is required for cell division which is induced by $\beta \mathrm{C} 1$.

\section{Conclusions}

From all these related results it has been concluded that the DEGs in the response of $\beta C 1$ of ChLCB under $35 \mathrm{~S}$ cauliflower promoter are related to the chloroplast and mitochondria and are involved in the ATP synthesis, act as electron carriers for respiration and photosynthesis processes. These DEGs play an important role in plant growth and development, cell protection, defence processes, replication mechanisms and detoxification responses as illustrated in Figure 3.

\section{Methods}

\section{Cloning of $\beta C 1$ of Chilli leaf curl betasatellite in pJIT163}

The $\beta C 1$ of $C h L C B$ was cloned under the control of the cauliflower mosaic virus 35S promoter in the pJIT163 plant expression vector. A set of primers $(\mathrm{Ch} \beta \mathrm{C} 135 \mathrm{~S}(\mathrm{~F})$ 5'-GCAAGCTTATGCACCACGTATATGAATTATGTC C-3'/ChßC135S(R) 5' - GCGAATTCTCACACACACACATTCGTACATAC-3'; having EcoRI and HindIII restriction sites, respectively) were designed to the reported sequence (accession no. AJ316032) to amplify a 450 bp DNA fragment containing the ChLCB $\beta C 1$ gene. The fragment was amplified with an initial $94^{\circ} \mathrm{C}$ for $5 \mathrm{~min}$ followed by 30 cycles of $94^{\circ} \mathrm{C}$ for $1 \mathrm{~min}, 50^{\circ} \mathrm{C}$ for $1 \mathrm{~min}, 72^{\circ} \mathrm{C}$ for $1 \mathrm{~min}$. A final extension at $72^{\circ} \mathrm{C}$ for 10 min was included. The amplification product was analyzed by $1 \%$ agarose gel electrophoresis. The amplified fragment and PJIT163 vector were restricted with EcoRI and HindIII restriction enzymes at $37^{\circ} \mathrm{C}$ overnight, precipitated with phenol-chloroform and ligated at $16^{\circ} \mathrm{C}$ overnight. The ligated product was transformed 


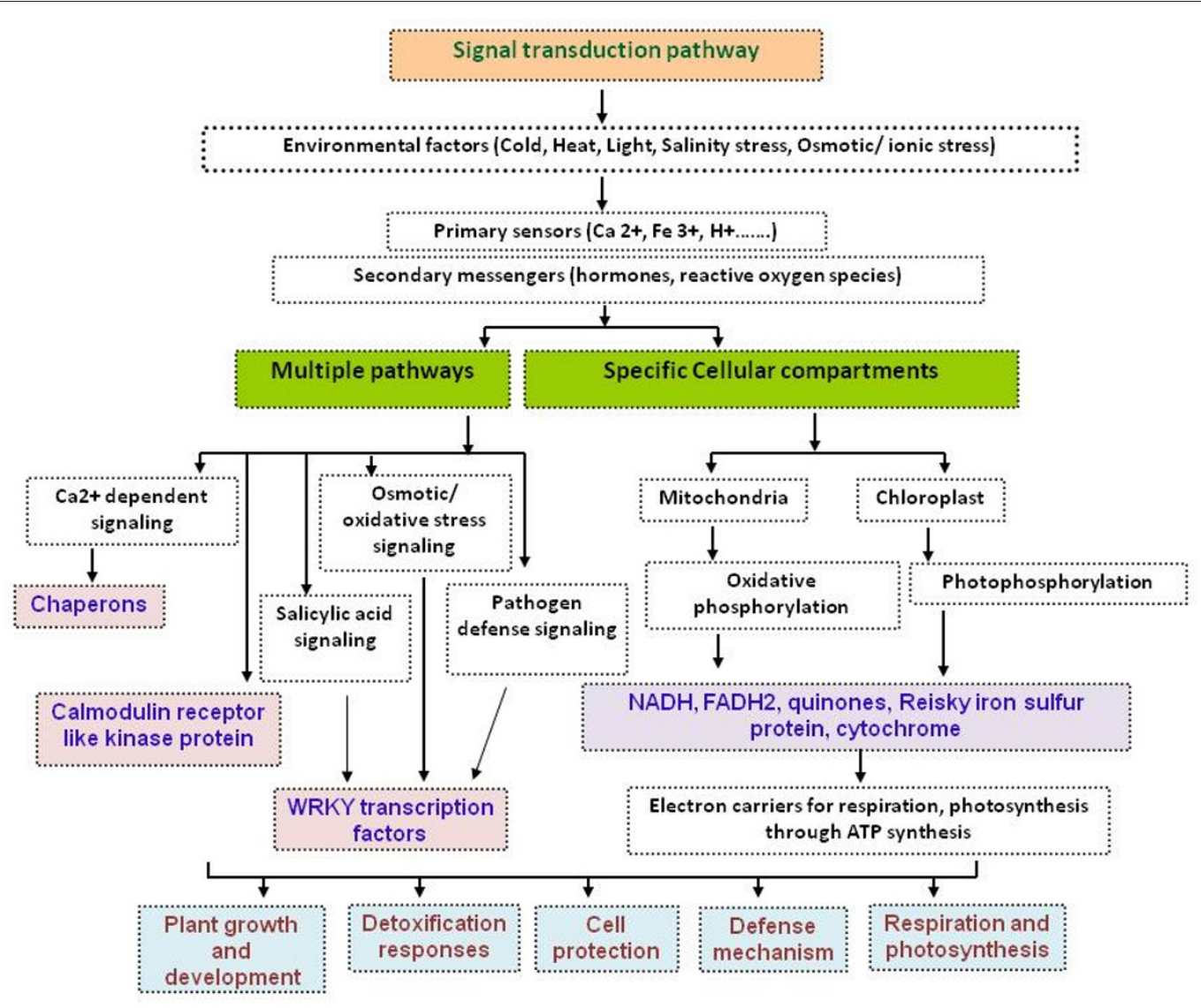

Figure 3 Schematic pathway showing the involvement of the differentially expressed genes (DEGs) in signal transduction pathways. DEGs isolated from $N$. tabacum at two and four days after infiltration in response of $\beta C 1$ are involved in different pathways during host protein interactions and also segregate in specific cellular compartments. Chaperons, CRCK2 and WRKY transcription factors involved in $\mathrm{Ca}^{+}$dependent signalling, salicylic acid signalling, osmotic and oxidative stress signalling and pathogen defence signalling pathways. In contrast, NADH, Reisky iron sulphur protein and quinone protein are related to mitochondrial and chloroplast sysstems and act as electro carriers for respiration, photosynthesis by ATP synthesis. The collective role of these DEGs are in defence, cell protection, respiration, photosynthesis, detoxification, plant growth and development.

Table 5 Differentially expressed genes (DEGs) and their identities

\begin{tabular}{|c|c|c|c|c|}
\hline DEG & $\begin{array}{l}\text { Length of } \\
\text { amplified } \\
\text { fragment }\end{array}$ & Identity & $\begin{array}{l}\text { Accession } \\
\text { No. }\end{array}$ & Identity \\
\hline & & Genes differentially expressed at two days after inoculation & & \\
\hline SAA & 287 & S. lycopersicum WRKY transcription factor Ild-1 splice & AY157059 & $(76 \%)$ \\
\hline SAB & 231 & $\begin{array}{l}\text { Putative Rieske iron-sulfur protein }[\text { A. thaliana]Length }=539 \text {, Rieske iron-sulfur protein Tic55 }[\text { P. } \\
\text { sativum] Length }=553\end{array}$ & $\begin{array}{l}\text { NM128041 } \\
\text { AJ000520 }\end{array}$ & $\begin{array}{l}(68 \%) / \\
(73 \%)\end{array}$ \\
\hline SAC & 386 & $\begin{array}{l}\text { N. tabacum mitochondrial DNA, complete genome Length }=430597 \text { : NADH dehydrogenase } \\
\text { subunit } 1 \text { and NADH dehydrogenase subunit } 2,846 \mathrm{bp} \text { at } 5^{\prime} \text { side }\end{array}$ & BA000042 & $(93 \%)$ \\
\hline \multirow[t]{2}{*}{ SAD } & 262 & Quinonprotein alcohol dehydrogenase like [M. truncatula] & $\begin{array}{l}\text { ABE84009 } \\
\text { ABE86610 }\end{array}$ & $(47 \%)$ \\
\hline & & Genes differentially expressed at four days after inoculation & & \\
\hline SA1 & 442 & Trigger factor (Chaperone protein) & AE017283 & $(99 \%)$ \\
\hline SA2 & 688 & A. thaliana calmodulin-binding receptor-like kinase 2 (CRCK2) & NM116255 & $(72 \%)$ \\
\hline SA3 & 772 & Polyribonucleotide nucleotidyltransferase & CP000323 & $(92 \%)$ \\
\hline SA4 & 263 & Chromosomal replication initiator protein DnaA & CP000653 & $(90 \%)$ \\
\hline
\end{tabular}


Table 6 Result analysis of DEGs through KOBAS; KO Based Annotation System for the pathway identification

\begin{tabular}{llllllll}
\hline Sequence identifier & KO term & KO definition & Rank & E-value & Score & Identity (\%) & Blast hit \\
\hline SA3 & K00962 & Polyribonucleotide nucleotidyltransferase & 1 & $1 \mathrm{e}-111$ & 404.0 & 96.64 & Pcr. Pcryo 0080 \\
\hline
\end{tabular}

Each row corresponds to a query DNA or protein input by the user. The first column contains sequence identifier extracted from the input. The second column contains the assigned KO terms hyperlinked to detailed description in KEGG. The third column contains KO term definition that this protein sequence belongs to this available protein in this program. The fourth to seventh columns shows the rank, e-value, score and identity of the BLAST hit. The last column contains the gene ID of the hit hyperlinked to the KEGG GENES dataset database.

into E. coli 10b. The transformation mixture was then spread on $100 \mathrm{mg} / \mathrm{ml} \mathrm{LB}$ ampicillin petri plates after incubation for one $\mathrm{h}$ at $37^{\circ} \mathrm{C}$. Plates were incubated overnight at $37^{\circ} \mathrm{C}$ and the next day colonies were cultured in LB containing ampicillin and placed overnight in a shaking water bath at $37^{\circ} \mathrm{C}$. Plasmid isolation from cultures was performed by miniprep method and recombinant clone was confirmed by digestion with EcoRI and HindIII. The resultant recombinant clone was named $\mathrm{pSA} \beta \mathrm{C} 135 \mathrm{~S}$.

\section{Transfer of expression cassette to binary vector and transformation of Agrobacterium tumefaciens}

pSA 3 C135S and pGreen0029 were restricted with XhoI and $\mathrm{XbaI}$ endonuclease, ethanol precipitated and ligated at $16^{\circ} \mathrm{C}$ for $18 \mathrm{~h}$. This was used for transformation into $E$. coli and colonies were confirmed by restriction analysis. Both pGreen0029 and pGreen0029 containing the expression cassette were transformed into Agrobacterium tumefaciens strain (GV 3101) by electroporation. The transformation mixture was then spread on LB medium plates containing $50 \mu \mathrm{g} / \mathrm{ml}$ of kanamycin, $25 \mu \mathrm{g} / \mathrm{ml}$ of rifampicin and $100 \mu \mathrm{g} / \mathrm{ml}$ tetracycline antibiotics, after a one hour incubation at $28^{\circ}$ C. Plates were incubated at $28^{\circ} \mathrm{C}$ until colonies appeared. After 48 hours, colonies were grown in LB liquid medium containing $50 \mu \mathrm{g} / \mathrm{ml}$ of kanamycin, 25 $\mu \mathrm{g} / \mathrm{ml}$ of rifampicin and $100 \mu \mathrm{g} / \mathrm{ml}$ tetracycline, and placed at $28^{\circ} \mathrm{C}$ for $48 \mathrm{~h}$. The transformants were confirmed by PCR analysis using the primers $\mathrm{Ch} \beta \mathrm{C} 135 \mathrm{~S}$ (F)/Ch $\beta C 135 \mathrm{~S}(\mathrm{R})$.

\section{Agroinfiltration of plants}

Agrobacterium cultures were grown at $28^{\circ} \mathrm{C}$ for $48 \mathrm{~h}$ in liquid LB medium containing $50 \mu \mathrm{g} / \mathrm{ml}$ of kanamycin and $25 \mu \mathrm{g} / \mathrm{ml}$ of rifampicin. The bacterial cells were pelleted at $4000 \mathrm{rpm}$ for $10 \mathrm{~min}$ at $20^{\circ} \mathrm{C}$ and resuspended in $10 \mathrm{mM} \mathrm{MgCl}$ and $150 \mu \mathrm{g}$ of acetosyringone per ml. After a three hour incubation cells were infiltrated into young, fully expanded leaves of 4 week- old $N$. tabacum plants using a $5 \mathrm{ml}$ syringe.

\section{Isolation of messenger RNA and CDNA synthesis}

Infiltrated of $N$. tabacum leaves infiltrated with pGreen0029 and pGreen0029 containing the $\beta C 1$ expression cassette were collected two and four days after inoculation in liquid nitrogen. Total RNA was extracted using Trizol reagent (Invitrogen, USA) following the manufacturer's instructions. The integrity and purity of total RNA isolated from infected leaf samples was assessed by electrophoresis on $1 \%$ agarose gels. The messenger RNA was isolated from total RNA using oligo (dT) cellulose columns (MRC, USA) according to the manufacturer's instructions. The loaded columns were washed with binding buffer and mRNA was eluted. The eluted mRNA was precipitated and dissolved in DEPC treated water. Messenger RNA resulting from two and four days post infiltration samples were reverse transcribed to cDNA using Revert Aid H- First Strand cDNA synthesis kit, (Fermentas, USA). Three reverse transcription reactions were carried out for each mRNA using three different anchored (T11M) primers (where M may be G, C or A). The products of reverse transcriptions (cDNA) were stored at $-20^{\circ}$ $\mathrm{C}$ for differential display PCR amplifications.

\section{Differential display analysis}

PCR amplification of each cDNA (synthesized from mRNA isolated from two and four days post inoculation samples) was carried out in combination with one of the three anchored primers and one of the twenty arbitrary

Table 7 Summary of purine and pyrimidine metabolic pathways of Polynucleotide nucleotidyl transferase

\begin{tabular}{|c|c|c|c|c|c|}
\hline Query gene & Pathway & Count and ratio & p-value & q-value & Web site \\
\hline SA3 & Pyrimidine metabolism & $1 / 100 \% 44 / 1.53 \%$ & 0.0153417015342 & 0.023709902371 & $\begin{array}{l}\text { http://www.genome.jp/kegg/catalog/org_list.html } \\
\text { http://kobas.cbi.pku.edu.cn/help.do } \\
\text { http://kobas.cbi.pku.edu.cn } \\
\text { http://www.genome.jp/ }\end{array}$ \\
\hline$\overline{S A 3}$ & Purine metabolism & $1 / 100 \%$ 68/2.37\% & 0.023709902371 & 0.023709902371 & \\
\hline
\end{tabular}

Table 4 described the first column shows the name of the pathway. The second column lists the number and percentage of input genes or proteins involved in the pathway (top red in color) and the number and percentage of background genes or proteins involved in the pathway (bottom green in color). The third and fourth columns list the $p$-value and q-value of the statistical significance, respectively. Purine and pyrimidine metabolic pathways of (SA3) polynucleotide nucleotidyltransferase that is an RNA binding protein and involved in RNA degradation. 
primers of the B-Series (as indicated in Table 1), providing 60 combinations in case of four days post inoculation and 29 combinations in the case of two days post inoculation. PCR was carried out in a final reaction volume of $50 \mu \mathrm{l}$ containing $2.5 \mu \mathrm{l}(100 \mathrm{ng} / \mu \mathrm{l}$ and $10 \mathrm{ng} / \mu \mathrm{l})$ of first strand cDNA, $5 \mu \mathrm{l}$ of $10 \times$ PCR buffer, $4 \mu \mathrm{lgCl}_{2}$ ( $25 \mathrm{mM}), 1 \mu \mathrm{l}$ of dNTPs (10 mM each), $2 \mu \mathrm{l}$ of anchord primer $(250 \mathrm{ng} / \mu \mathrm{l}), 8 \mu \mathrm{l}$ of arbitrary primer $(100 \mathrm{ng} / \mu \mathrm{l})$,

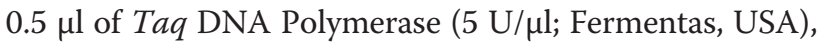
$27 \mu \mathrm{l}$ double distilled $\mathrm{H}_{2} \mathrm{O}$. The PCR amplification protocol included first cycle at $94^{\circ} \mathrm{C}$ for 4 min followed by 45 cycles of $36^{\circ} \mathrm{C}$ for $2 \min , 72^{\circ} \mathrm{C}$ for $1 \mathrm{~min}, 94^{\circ} \mathrm{C}$ for $1 \mathrm{~min}$; and a final extension step at $72^{\circ} \mathrm{C}$ for $10 \mathrm{~min}$. The amplified PCR products were resolved on $1 \%$ agarose gel and stained with ethidium bromide.
Cloning and sequencing of differentially expressed genes (DEGs)

The differentially expressed bands were excised from the gel and extracted by QIAGEN gel extraction kit and DNA extraction kit (MBI, Fermentas). The eluted bands were ligated into pTZ57RT, and transformed into E. coli TOP 10 by the heat shocked method. Plasmid DNA was isolated using the miniprep method and clones were confirmed by restriction analysis using EcoRI and PstI restriction enzymes. Purified clones were sequenced using M13 (-20) forward and M13 (-26) reverse primers and BigDye terminator v 3.1 ABI Prism 310 Genetic analyzer (Applied Biosystems, USA) as decribed by the manufacturer. Sequence information was stored, assembled and analysed using the Lasergene sequence

Table 8 After two days differentially expressed genes (DEGs) primer sequences for quantitative real time PCR

\begin{tabular}{|c|c|c|}
\hline Name of genes & Sequences of primers & MERS \\
\hline \multicolumn{3}{|c|}{ Primer sequences two days post inoculation of $\beta C 1$ of $C h L C B$ for Q-RTPCR analysis } \\
\hline \multirow[t]{6}{*}{ SAA } & SAA F: GAGACCCGGGATGTCCTGGCAAGAAAGCAT & (30 MERS) \\
\hline & SAAQPCR:AATTACAAAAGAGCCCCTAAATCCCTAAGC & (30 MERS) \\
\hline & SAA F2: GGAGAGGGCAACCGATGA & (18 MERS) \\
\hline & SAA QPCR2: CCCCTAAATCCCTAAGC & (17 MERS) \\
\hline & SAA F3: GGGACGATCGCCGGCGCCGG & (20 MERS) \\
\hline & SAA QPCR3: TCACTACCCACCGTATC & (17 MERS) \\
\hline \multirow[t]{6}{*}{ SAB } & SAB F: AATCCCCGGGATGTATGCTCCGAATCCCGC & (30 MERS) \\
\hline & SABQPCR:CATAGTGATGTCGAAAGCAAAAGTAGGGCC & (30 MERS) \\
\hline & SAB F2: GTATGCTCCGAATCCCG & (17 MERS) \\
\hline & SAB QPCR2: CAAAAGTAGGGCCTTCC & (17 MERS) \\
\hline & SAB F3: CCAGCTAAGGGAGGAATC & (18 MERS) \\
\hline & SAB QPCR3: GGCCTTCCACTGTCTTCCTG & (20 MERS) \\
\hline \multirow[t]{6}{*}{ SAC } & SAC F: TCCCCCCGGGATGTTTCAGGTTCACATGAA & (30 MERS) \\
\hline & SACQPCR:TAGGCTATAGGTGGGGGACAATGTAGACTG & (30 MERS) \\
\hline & SAC F2: CACAACACGACTCCCTAC & (18 MERS) \\
\hline & SAC QPCR2: GAAGTTGGGCCCACCTG & (17 MERS) \\
\hline & SAC F3: CTCCACGAGTCTTCATCCCC & (20 MERS) \\
\hline & SAC QPCR3: CCGAGATCGAGAGCTTTC & (18 MERS) \\
\hline \multirow[t]{6}{*}{ SAD } & SA D F; GGTGCCCGGGATGGCAGATCAGTGGAGTTG & (30 MERS) \\
\hline & SADQPCR: GATTAGGTTCCCGTAGATAGATGCATAACC & (30 MERS) \\
\hline & SAD F2: AAGTTCTAATTCGGAGGG & (18 MERS) \\
\hline & SAD QPCR2: TAGATAGATGCATAA & (17 MERS) \\
\hline & SAD F3: GTTAGCTTACTTAAACAG & (20 MERS) \\
\hline & SAD QPCR3: TAGATGCATAACC & (17 MERS) \\
\hline
\end{tabular}


Table 9 After four days differentially expressed genes (DEGs) primer sequences for quantitative real time PCR

\begin{tabular}{|c|c|c|}
\hline Name of genes & Sequences of primers & MERS \\
\hline \multicolumn{3}{|c|}{ Primer sequences four days post inoculation of $\beta C 1$ of $\mathrm{ChLCB}$ for Q-RTPCR analysis } \\
\hline \multirow[t]{6}{*}{ SA1 } & SA1 F: GTCACCCGGGATGTGACGCCGACGGTCAAT & (30 MERS) \\
\hline & SA1 QPCR: GGGCCGCACCATGGTCCTGCTGACTTACCG & (30 MERS) \\
\hline & SA1 F2: GACGGTCAATCCATGTAT & (18 MERS) \\
\hline & SA1 QPCR2: GGTGTCAGGAGACCCCTTCCA & (17 MERS) \\
\hline & SA1 F3: GGTAGAGCCCCAGTCTTCCA & (20 MERS) \\
\hline & SA1 QPCR3: GCACCCGCCCAACTCCACGG & (17 MERS) \\
\hline \multirow[t]{6}{*}{ SA2 } & SA2 F: AATACCCGGGATGATAAACATTTGGGGG & (30 MERS) \\
\hline & SA2 QPCR: CCAATGTCTAGTCTTGATGCAAAATCAA & (30 MERS) \\
\hline & SA2 F2: CTAGTAAAGTTTTATGGATTCTTGGA & (17 MERS) \\
\hline & SA2 QPCR2: ATGGATAATAGGGTGATCAGT & (17 MERS) \\
\hline & SA2 F3: CACTTGGACTGTGGTCCTG & (18 MERS) \\
\hline & SA2 QPCR3: GTCAGCCACCTTAGCTCG & (20 MERS) \\
\hline \multirow[t]{6}{*}{ SA3 } & SA3 F: CGCGCCCGGGATGCATCTAGATTGTCCACA & (30 MERS) \\
\hline & SA3 QPCR: TCAATCAGACGCGAGGTTAAGGTTTCAGAC & (30 MERS) \\
\hline & SA3 F2: GAAGGCTATGTAAACGAG & (18 MERS) \\
\hline & SA3 QPCR2: GCTCTTCAAGGGTCGGGTTCAG & (17 MERS) \\
\hline & SA3 F3: GACTTGGTCGTCGCTGGTA & (20 MERS) \\
\hline & SA3 QPCR3: GCTTGATCGCGTACAGG & (18 MERS) \\
\hline \multirow[t]{6}{*}{ SA4 } & SA4 F: GCGACCCGGGAtGCATCTAGATTTGGGGGA & (30 MERS) \\
\hline & SA4 QPCR: AGAAACAGAAGATCTCTGGCTCAGTTTAGG & (30 MERS) \\
\hline & SA4 F2: TTCATGATTGTTGGCGCAC & (18 MERS) \\
\hline & SA4 QPCR2: CTGATCTTCCTGTGGA & (17 MERS) \\
\hline & SA4 F3: CGGCATGACCCTGTGTAA & (20 MERS) \\
\hline & SA4 QPCR: GGGGGACTCGCGCCAGG & (17 MERS) \\
\hline
\end{tabular}

analysis package (DNAStar Inc., Madison, WI, USA) running on an IBM compatible PC.

\section{Analysis of DEGs using NCBI, KOBAS and RT-PCR}

The nucleotide sequences were analyzed using BLAST; for blastn and blastx algorithms in NCBI. Clusters of orthologus group of proteins were identified at NCBI http://www.ncbi.nlm.nih.gov/Blast.cgi and KEGG orthology http://www.genome.jp/. Real time quantitative PCR was performed to analyse expression of DEGs in relation to a reference gene and the calibrators at a constant level of fluorescence. These were calculated with Delta Delta $(\mathrm{Ct})$, Livak and the Pfaffi mathematical models of quantitative real time PCR method $[57,58]$. For RT-PCR each sample was used in triplicate and the experiment was repeated three times to confirm the reproducibility of result. The sequences of RT-PCR primers are shown in Table 8 and 9.

\section{Acknowledgements}

The work was supported by a Ministry of Science and Technology (MOST) project. R.W.B. is supported by the Higher Education Commission (Pakistan) under the "Foreign Faculty Hiring Program".

\section{Authors' contributions}

SA conducted all the experimental work and drafted the manuscript. $A B$ and IA helped in the RT-PCR and DD-PCR analysis. SM and RWB together designed the experiments. IA and SM had proof-read and finalized the manuscript. All authors read and approved the final manuscript.

\section{Competing interests}

The authors declare that they have no competing interests.

Received: 10 October 2010 Accepted: 30 December 2010 Published: 30 December 2010 


\section{References}

1. Hanley-Bowdoin L, Settlage SB, Orozco BM, Nagar S, Robertson D: Geminviruses: models for plant DNA replication, transcription, and cell cycle regulation. Crit Rev Plant Sci 1999, 18:71-106.

2. Laufs J, Traut W, Heyraud F, Matzeit V, Rogers SG, Schell J, Gronenborn B: In vitro cleavage and joining at the viral origin of replication by the replication initiator protein of tomato yellow leaf curl virus. Proc Natl Acad Sci USA 1995, 92:3879-3883.

3. Mansoor S, Briddon RW, Zafar Y, Stanley J: Geminivirus disease complexes: an emerging threat. Trends Plant Sci 2003, 8:128-134.

4. Saunders K, Bedford ID, Yahara T, Stanley J: The earliest recorded plant virus disease. Nature 2003, 422:831

5. Saeed M, Behjatnia SA, Mansoor S, Zafar Y, Hasnain S, Rezaian MA: A single complementary-sense transcript of a geminiviral DNA $\beta$ satellite is determinant of pathogenicity. Mol Plant Microbe Interact 2005, 18:7-14.

6. Saunders K, Bedford ID, Briddon RW, Markham PG, Wong SM, Stanley J: A unique virus complex causes Ageratum yellow vein disease. Proc Natl Acad Sci USA 2000, 97:6890-6895.

7. Zhou X, Xie Y, Peng Y, Zhang Z: Malvastrum yellow vein virus, a new Begomovirus species associated with satellite DNA molecule. Chi Sci Bull 2003, 48:2205-2209.

8. Hussain M, Mansoor S, Amin I, Iram S, Zafar Y, Malik KA, Briddon RW: First report of cotton leaf curl disease affecting chili peppers. Plant Pathol 2003, 56:906.

9. Briddon RW, Bull SE, Amin I, Idris AM, Mansoor S, Bedford ID, Dhawan P, Rishi N, Siwatch SS, Abdel-Salam AM, Brown JK, Zafar Y, Markham PG: Diversity of DNA $\beta$, a satellite molecule associated with some monopartite begomoviruses. Virology 2003, 312:106-121.

10. Qazi J, Amin I, Mansoor S, labal MJ, Briddon RW: Contribution of the satellite encoded gene $\beta C 1$ to cotton leaf curl disease symptoms. Virus Res 2007, 128:135-139.

11. Soosaar JL, Burch-Smith TM, Dinesh-Kumar SP: Mechanisms of plant resistance to viruses. Nat Rev Microbiol 2005, 3:789-798.

12. Huang Z, Yeakley JM, Garcia EW, Holdridge JD, Fan JB, Whitham SA Salicylic acid-dependent expression of host genes in compatible Arabidopsis-virus interactions. Plant Physiol 2005, 137:1147-1149.

13. Sui C, Fan Z, Wong SM, Li H: Cloning of cDNAs encoding the three subunits of oxygen evolving complex in Nicotiana benthamiana and gene expression changes in tobacco leaves infected with Tobacco mosaic virus. Physiol Mol Plant Pathol 2006, 68:61-68.

14. Havelda Z, Maule AJ: Complex spatial responses to cucumber mosaic virus infection in susceptible Cucurbita pepo cotyledons. Plant Cell 2000, 12:1975-1986.

15. Kang BC, Yeam I, Jahn MM: Genetics of plant virus resistance. Annu Rev Phyto 2005, 43:581-621.

16. Liang P, Pardee AB: Differential display of eukaryotic messenger RNA by means of the polymerase chain reaction. Science 1992, 257:967-971.

17. Yun-Jee KIM, Chae-II KWAK, Young-Yun GU, In-Taek H, Chun JongYoon: Annealing control primer system for identification of differentially expressed genes on agarose gels. BioTechniques 2004, 36:424-434

18. Crauwels M, Winderickx J, de Winde JH, Thevelein JM: Identification of genes with nutrient-controlled expression by PCR-mapping in the yeast Saccharomyces cerevisiae.. Yeast 1997, 13:973-984.

19. Gross C, Watson K: Application of mRNA differential display to investigate gene expression in thermotolerant cells of Saccharomyces cerevisiae.. Yeast 1998, 14:431-442.

20. Tawe WN, Eschbach ML, Walter RD, Henkle-Duhrsen K: Identification of stress-responsive genes in Caenorhabditis elegans using RT-PCR differential display. Nucleic Acids Res 1998, 26:1621-1627

21. Cui X, Li G, Wang D, Hu D, Zhou X: A begomovirus DNA $\beta$ encoded protein binds DNA, functions as a suppressor of RNA silencing, and targets the cell nucleus. J Virol 2005, 79:10764-10775.

22. Gopal P, Pravin Kumar P, Sinilal B, Jose J, Kasin Yadunandam A, Usha R: Differential roles of $C 4$ and $\beta C 1$ in mediating suppression of posttranscriptional gene silencing: evidence for transactivation by the C2 of Bhendi yellow vein mosaic virus, a monopartite begomovirus. Virus Res 2007, 123.9-18.

23. Saunders K, Norman A, Gucciardo S, Stanley J: The DNA $\beta$ satellite component associated with ageratum yellow vein disease encodes an essential pathogenicity protein ( $\beta C 1$ ). Virology 2004, 324:37-47.
24. Briddon RW, Mansoor S, Bedford ID, Pinner MS, Saunders K, Stanley J, Zafar Y, Malik KA, Markham PG: Identification of DNA components required for induction of cotton leaf curl disease. Virology 2001, 285:234-243

25. Jose J, Usha R: Bhendi yellow vein mosaic disease in India is caused by association of a DNA $\beta$ satellite with a begomovirus. Virology 2003, 305:310-317.

26. Sharma P, Matsuda N, Bajet NB, Ikegami M: Molecular analysis of new isolates of Tomato leaf curl Philippines virus and an associated betasatellite occurring in the Philippines. Arch Virol 2010, DOI: 10.1007/ s00705-010-0837-3.

27. Zhang Y, Fan W, Kinkema M, Li X, Dong X: Interaction of NPR1 with basic leucine zipper protein transcription factors that bind sequences required for salicylic acid induction of the PR-1 gene. Proc Natl Acad Sci USA 1999, 96:6523-6528.

28. Eulgem T, Rushton PJ, Robatzek S, Somssich IE: The WRKY superfamily of plant transcription factors. Trends Plant Sci 2000, 5:199-206.

29. Chen C, Chen Z: Isolation and characterization of two pathogen- and salicylic acid-induced genes encoding WRKY DNA-binding proteins from tobacco. Plant Mol Biol 2000, 42:387-396.

30. Vandenabeele S, Van der Kelen K, Dat J, Gadjev I, Boonefaes T, Morsa S, Rottiers P, Slooten L, Van Montagu M, Zabeau M, et al: A comprehensive analysis of hydrogen peroxide-induced gene expression in tobacco. Proc Natl Acad Sci USA 2003, 100:16113-16118.

31. Rieske JS, Zaugg WS, Hansen RE: Studies on the electron transfer system. LIX. Distribution of iron and of the component giving an electron paramagnetic resonance signal at $\mathrm{g}=1.90$ in subfractions of complex 111. J Biol Chem 1964, 239:3023-3030

32. Beckmann JD, Ljungdahl PO, Trumpower BL: Mutational analysis of the mitochondrial Rieske iron-sulfur protein of Sacchammyces cerevisiae. 1. Construction of a RIPI deletion strain and isolation of temperaturesensitive mutants. J Biol Chem 1989, 264:3713-3722.

33. Trumpower $B L, E d w a r d s ~ C A$ : Purification of a reconstitutively active iron-sulfur protein (oxidation-factor) from succinate-cytochrome $c$ reductase complex of bovine heart mitochondria. J Biol Chem 1979, 254:8697-8706.

34. Huang J, Struck F, Matzinger DF, Levings CS: Functional analysis in yeast of cDNA coding for the mitochondrial Rieske iron-sulfur protein of higher plants. Proc Natl Acad Sci USA 1991, 88:10716-10720.

35. Burrows PA, Sazanov LA, Svab Z, Maliga P, Nixon PJ: Identification of a functional respiratory complex in chloroplasts through analysis of tobacco mutants containing disrupted plastid ndh genes. EMBO J 1998 17:868-876.

36. Sazanov LA, Burrows PA, Nixon PJ: The plastid ndh gene code for an $\mathrm{NADH}$-specific dehydrogenase: Isolation of a complex I analogue from peathylakoid membranes. Proc Natl Acad Sci USA 1998, 95:1319-1324

37. Horst M, Oppliger W, Rospert S, Schonfeld HJ, Schatz G, Azem A: Sequential action of two Hsp70 complexes during protein import into mitochondria. EMBO J 1997, 16:1842-1849.

38. Neupert W: Protein import into mitochondria. Annu Rev Biochem 1997 66:863-917.

39. Ryan MT, Naylor DJ, Hoj PB, Clark MS, Hoogenraad NJ: The role of molecular chaperones in mitochondrial protein import and folding. Int Rev Cytol 1997, 174:127-193.

40. Zielinski RE: Calmodulin and calmodulin binding proteins in plants. Annu Rev Plant Physiol Plant Mol Biol 1998, 46:697-725.

41. White PJ, Broadley MR: Calcium in plants. Ann Bot 2003, 92:487-511.

42. Trewavas A: Signal perception and transduction. In BB Buchanan, W Gruissem, RL Jones, eds, Biochemistry and molecular biology of plants. American Society of Plant Biologists Rockville 2000, 1:962-973.

43. Yang T, Chaudhuri S, Yang L, Chen Y, Poovaiah BW: Calcium/calmodulin up-regulates a cytoplasmic receptor-like kinase in plants. J Biol Chem 2004, 279:42552-42559

44. Chan YP, Lee JH, Yoo JH, Moo BC, Choi MS, Kang YH, Lee SM, Kim HS, Kang KY, Chung WS, Lim CO, Cho MJ: WRKY group Ild transcription factors interact with calmodulin. FEBS Lett 2005, 579:1545-1550.

45. Snedden W, Fromm H: Calmodulin as a versatile calcium signal transducer in plants. New Physiologist 2001, 151:35-66

46. Hoeflich KP, Ikuru M: Calmodulin in action: diversity in target recognition and activation mechanisms. Cell 2002, 108:739-742. 
47. Bernstein JA, Lin PH, Cohen SN, Lin-Chao S: Global analysis of Escherichia coli RNA degradosome function using DNA microarrays. Proc Natl Acad Sci USA 2004, 101:2758-2763.

48. Yamanaka K, Inouye M: Selective mRNA degradation by polynucleotide phosphorylase in cold shock adaptation in Escherichia coli. J Bacteriol 2001, 183:2808-2816.

49. Favaro R, Deho G: Polynucleotide phosphorylase-deficient mutants of Pseudomonas putida. J Bacteriol 2003, 185:5279-5286.

50. Goverde RL, Huisin't Veld JH, Kusters JG, Mooi FR: The psychrotrophic bacterium Yersinia enterocolitica requires expression of pnp, the gene for polynucleotide phosphorylase, for growth at low temperature $\left(5^{\circ} \mathrm{C}\right)$. Mol Microbiol 1998, 28:555-569.

51. Symmons MF, Jones GH, Luisi BF: A duplicated fold is the structural basis for polynucleotide phosphorylase catalytic activity, processivity, and regulation. Structure Fold Des 2000, 8:1215-1226.

52. Leszczyniecka M, DeSalle R, Kang DC, Fisher PB: The origin of polynucleotide phosphorylase domains. Mol Phylogenet Evol 2004, 31:123-130.

53. Kudla J, Hayes R, Gruissem W: Polyadenylation accelerates degradation of chloroplast mRNA. EMBO J 1996, 15:7137-7146.

54. Yehudai-Resheff S, Hirsh M, Schuster G: Polynucleotide phosphorylase functions as both an exonuclease and a poly $(\mathrm{A})$ polymerase in spinach chloroplasts. Mol Cell Biol 2001, 21:5408-5416.

55. Leszczyniecka M, Kang DC, Sarkar D, Su ZZ, Holmes M, Valerie K, Fisher PB: Identification and cloning of human polynucleotide phosphorylase, hPNPase old-35, in the context of terminal differentiation and cellular senescence. Proc Natl Acad Sci USA 2002, 99:16636-16641.

56. Sarkar D, Leszczyniecka M, Kang DC, Lebedeva IV, Valerie K, Dhar K, Pandita S, Fisher PB: Down-regulation of Myc as a potential target for growth arrest induced by human polynucleotide phosphorylase (hPNPaseold-35) in human melanoma cells. J Biol Chem 2003, 278:24542-24551.

57. Pfaffi MW, Hageleit M: Validities of mRNA quantification using recombinant RNA and recombinant DNA external calibration curves in real time RT-PCR. Biotechnol Lett 2001, 23:275-282.

58. Michael WP: A new mathematical model for relative quantification in real time RT-PCR. Nucleic Acids Res 2001, 29:2001-2007.

doi:10.1186/1743-422X-7-373

Cite this article as: Andleeb et al:: Transient expression of $\beta C 1$ protein differentially regulates host genes related to stress response,

chloroplast and mitochondrial functions. Virology Journal 2010 7:373.

\section{Submit your next manuscript to BioMed Central and take full advantage of:}

- Convenient online submission

- Thorough peer review

- No space constraints or color figure charges

- Immediate publication on acceptance

- Inclusion in PubMed, CAS, Scopus and Google Scholar

- Research which is freely available for redistribution

Submit your manuscript at www.biomedcentral.com/submit 